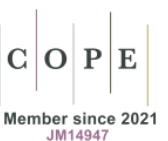

JM14947
Multicultural Shakespeare:

Translation, Appropriation and Performance vol. 23 (38), 2021

https://doi.org/10.18778/2083-8530.23.10

Andrzej Wicher ${ }^{*}$ (1)

\title{
The Inverted Initiation Rituals in Shakespeare with a Special Emphasis on Hamlet
}

\begin{abstract}
The article deals the possibility of applying Vladimir Propp's, basically anthropological idea of "the inverted ritual" to the interpretation of certain plays by William Shakespeare, particularly Hamlet. The said inversion concerns three rituals: the sacrificial ritual, where the passive and obedient victim suddenly rebels, or at least becomes difficult to control (which is the case, for example, of Ophelia in Hamlet); of the initiatory ritual, where the apparently benevolent master of the characters initiation is shown as a monster (which can be exemplified by Claudius, Hamlet's uncle); and of the matrimonial ritual, where the theoretically loving husband (more rarely wife), or lover, is revealed as a highly malicious and unpredictable creature, an example of which can be Hamlet himself. The article makes use of the work of such critics as G.K. Wilson, Harold Bloom, Vladimir Propp, René Girard, and Mircea Eliade.
\end{abstract}

Keywords: Shakespeare, Hamlet, initiation, ritual, reversal, myth, folktale.

\section{Introduction}

When we speak about the matter of initiation, we mean, first of all, the problem of the generation gap and the traditional ways of solving it. There is little doubt that the motif of a difficult relationship between the father and the son, in some cases also the daughter, is an important moment in all of Shakespeare's works. It is possible to look at this relationship in a rather placid way:

A father's goal is for his son to surpass him or simply carry on the honor of the family name. To try and avoid any mishaps, fathers advise their sons using the experience they have gained throughout their own lifetimes.

The same, it seems, is true of royalty, except that it is not only the family name on the line, but that of the entire country. In William Shakespeare's Richard II, the father figures of Gaunt and York, try to persuade Richard to set things straight in England again.

* University of Lodz, Poland. 
In Henry $I V$, it is Bolingbroke himself that bestows guidance upon his estranged son, Prince Henry, who seems to prefer the company of drunks and thieves to those in the court. His speech, delivered after he finds out about the Percy family rebellion, is intended to get his son to assume his responsibilities in a time of great need. (N.B. 1)

In this passage, it is tacitly assumed that fathers, or father figures, in Shakespeare are benevolent, and if they appear stern and censorious, it is for the good of the wayward son. Richard II represents a member of the younger generation, who foolishly assumes that he knows better-specifically, better than his uncles, John of Gaunt and Edmund of Langley, Duke of York, who act as not very empathetic, but still well-meaning counsellors and father substitutes - and, as a result, he loses everything. Prince Henry in Henry $I V$, on the other hand, finally listens to the voice of his royal father, and becomes a dutiful son, and later, after his father's death, a very serious and efficient, though short-lived, ruler.

In Richard II, however, York becomes ultimately disloyal to Richard: he takes up the cause of the rebel duke Henry Bolingbroke, who later becomes Henry IV. John of Gaunt, had he lived, might well have done the same, for after all he was Henry Bolingbroke's father. York's treacherousness does not prevent him from assuming a self-righteous attitude towards his own son, the Duke of Aumerle, whom he denounces as a traitor, for conspiring against the new king, and, had it not been for the intervention of his wife, the Duchess of York, he might have engineered his son's death. Thus, York is not only ineffective and unreliable as Richard's substitute father; he also shows that he can be his own son's worst enemy. To interpret him as a positive father-figure becomes almost impossible.

This role is certainly better performed in Henry IV by King Henry IV in relation to his son Prince Hal, later Henry V. But "better" hardly means "well" in this case. The king has to watch his son becoming a kind of gangster, who, without becoming implicated in any openly subversive activity, is still completely dismissive of his duties as the crown prince. Besides, the king, having been a rebel himself, and the person responsible for the death of his legal sovereign, Richard II, is hardly in a position to give lessons in loyalty to his own son. Henry IV's rebellious past casts a long shadow of illegitimacy over his, and not only his, reign. Logically, Henry V, as the son of a usurper, who profits from his usurpation, is a usurper, too. Later the problem of Henry IV's weak claim to the crown will lead to the outbreak of the tragic War of the Roses, which, being a civil war, caused a general collapse of public order in England.

Here we see that even in the early plays of Shakespeare, the problem of the real or substitute father's relation to his son is emphasized and shown in a light that is hardly idealistic. 


\section{The mechanism of the inversion}

My argument is that in Shakespeare, especially in his later plays, we come across something similar to what Vladimir Propp described as "inversion of the ritual" [Обращение обряда], which he defined in the following terms:

Formerly it was customary to kill aged people, but the wondertale narrates how an old man was spared. During the time that this custom existed, a person who showed mercy to the old man would have been held up to ridicule, perhaps castigated, or even punished; in the wondertale, the person who shows mercy to the old man is depicted as praiseworthy hero who acts wisely. Similarly, it was customary to sacrifice a virgin to the river whose flood ensured good crops. This would be done at the beginning of sowing and was supposed to facilitate the growth of the vegetation. But in the wondertale, the maiden is rescued from the monster by the hero. As long as the ritual existed, such a "liberator" would have been torn to pieces as the greatest of profaners. as one who jeopardized the well-being of the people, the crops. ... But with the decay of the once sacred system, the custom in which the virgin went (sometimes willingly) to her death became needless and repugnant, and the role of the protagonist switched to the former profaner who interfered with the sacrifice. (Propp, 1984: 101)

The ritual referred to here is clearly that of human sacrifice. This ritual was widely practised in Europe and in the Mediterranean in the Neolithic age, later to be replaced by animal sacrifice, as is graphically represented in the well-known Biblical story of Abraham's interrupted sacrifice of his son Isaac.

The quotation given above comes from Propp's book Historical Roots of the Wondertale, which is largely concerned with deriving the wondertale (known also as the fairy tale, or the tale of magic) from the ritual of initiation rather than the sacrificial ritual. The basic form of the initiation ritual is well known and there is no need to go into too much detail here. The two figures on whom this ritual is based are, first, the initiate, or initiand, who undergoes the rite of passage, (initiation), as result of which he or she is "reborn" and accepted in a new social role, and, second, the master of the initiation (guru), clearly a father figure, who plays the role of teacher and examiner, somebody who is often demanding, but generally benevolent, and who is glad at the initiate's final success in carrying out a series of difficult tasks.

Propp's idea of inversion applies also, or even best, to the ritual of initiation:

Between the ritual and the wondertale there is one important difference. In the ritual it is the youth's eyes that are plastered with a sticky substance, in the wondertale the same happens to the hag, or other similar characters. In other words, the myth or the wonder tale represents a precise inversion of the ritual. Why has such an inversion taken place? 
The ritual was something terrible and dreadful for children and their mothers, but it was regarded as necessary, which is why the one who took part in it gained something that could be called the magic power over the animal, the ritual was thus characteristic of the primitive hunting. The moment, however, the weapons became more accomplished, and agriculture was introduced, the new system of social organization made the old cruel rituals appear unnecessary and accursed, they turn, as it were, against their own perpetrators. If, during the ritual, the youth was blinded by the creature that tortures him and threatens to devour him, the myth, liberated from the ritual, becomes a means of protest. Something similar takes place in the case of the motif of burning, in the ritual, the children are being "burned", while in the wondertale, it is the children that burn the hag. (Propp, 2003: 74)

It follows, then, that the original master of the initiation, who had fulfilled the role of a stern but benevolent examiner, underwent a transformation into an enemy. Propp speaks, for example, about the early form of the fairy tale fiery dragon, the classic enemy of the hero, which had been originally a positive and helpful character (see Propp, 2003: 309-310). The psychological mechanism of this transformation is readily understandable, for almost every student feels occasionally that the examiner is, or could be, malicious or prejudiced. But in terms of the history of culture, in the fairy tale we find something more serious, a tendency to look at the ritual, both the initiatory and the sacrificial, from the point of view of the one who suffers, or the one who has been given a difficult task. Hence, the act of saving a prospective victim is no longer counted as spoiling the ceremony, but rather as a heroic feat; likewise the figure who assigns difficult tasks to the hero is no longer a respectable guru but rather an enemy who should be eliminated. It is not for nothing that fairy-tales are regarded as part of children's literature. They may not deal with childish matters, or in a childish way, but they resolutely side with the younger generation.

Consequently, we have to do here with two states of affairs, the more archaic one corresponding to the ritual, the other characteristic of myths and folktales, which are often rooted in the ritual, but essentially different from it. In the former, the initiate is under the supervision of the master, a spiritual guide, in whose interest it is to lead the initiate successfully through the process of initiation. But in the latter, the original meaning of the ritual is forgotten and often no longer makes sense. It is replaced with what might be called the hero's warpath, which leads towards the final success, often expressed in an advantageous marriage.

It is possible to establish a logical link between the ritual of initiation and the sacrificial ritual. Initiation was often logically connected with sacrifice because the conductor of the sacrifice had to be a worthy person, perhaps 
a qualified priest; that is, someone who had successfully undergone the ritual of initiation. For example,

In the Vedic cult, the sacrificer and his wife were required to undergo an initiation (diksha) involving ritual bathing, seclusion, fasting, and prayer, the purpose of which was to remove them from the profane world and to purify them for contact with the sacred world." (Faherty 2)

Both rituals may become inverted, so that the benevolent master of the initiation changes into a malicious enemy, while the ritual of sacrifice is no longer expected to be fulfilled but rather aborted, and the sacrificial animal, or person, escapes fate.

Mircea Eliade distinguished three types of initiation ritual. The first is the most widespread and concerns the process of becoming mature, and joining the society of grown-ups. The second is focused on secret societies of all kinds, and the third is what might be called priestly initiation, at the end of which the initiate becomes a priest, shaman, or medicine man. Initiation was often logically connected with sacrifice. The two latter types are similar, the major difference being "the ecstatic element" in the shamanic initiation (Eliade 24-26). ${ }^{1}$

Eliade draws our attention to an important aspect of the historical perception of initiation rituals:

We should not forget that the triumph of Christianity and its becoming a universal religion was exactly due to its having distanced itself from the climate of the Greek and Oriental mysteries, and its advertising itself as a religion of salvation, and this salvation being accessible to everybody. (Eliade 11)

"To everybody" means clearly: not only to the initiates. In other words, the foundations of Western civilization are connected with an act of rejecting a culture based on initiation, where what Max Weber called "salvation goods" can be acquired only by a narrow elite. As Eliade also notes, our culture is no longer dominated by Christianity and has become "radically desacralized" (Eliade 11). But the principle of free access to what should perhaps no longer be called "salvation goods", but rather "culture goods", has remained intact, even though "freely accessible" is not the same as "freely available". In our postChristian world we still believe in a society that is not dominated by some sectarian cliques, secret societies, or mafias, who reserve some special benefits for their members only. Whether our society really corresponds to those democratic, anti-elitist principles is another matter.

${ }^{1}$ The translation of all the passages from Eliade's book from French into English is mine. 
What, in this context, is the position of Shakespeare and his plays? He obviously must have known initiation mainly in the Christian context. The preparation for the Christian sacraments is here a case in point. Most of them have strongly initiatory aspects. But we should not forget that in Protestant England most sacraments, with the exception of Baptism and Holy Communion, were abolished. On the other hand, it is not at all clear to what extent Shakespeare identified himself with English Protestantism. It is, in my opinion, quite possible, though by no means certain, that he was, as some scholars suggest, a crypto-Catholic. ${ }^{2}$ The rise of Freemasonry, not long after Shakespeare's death, shows that there was a need in Europe for a cultural formation strictly based on initiation, the initiation of what Eliade calls the second type, that is, the one connected with joining secret societies.

The idea of connecting Shakespeare's plays with ancient rituals and their anthropological interpretation is not exactly a new one. There is, for example, an interesting book, Shakespeare's Comic Rites by Edward Berry (1984). Berry concentrates on Shakespeare's comedies, especially comedies, such as The Taming of the Shrew, A Midsummer Night's Dream, Twelfth Night, and As You Like It, that emphasize the motif of troubled courtship leading eventually to a marriage treated as the happy ending of the play. The ritual that is here analysed is that of marriage, which certainly may have some links with initiatory and sacrificial rituals, the most important of which is the structure of the rite of passage. There is also Naomi Conn Liebler's Shakespeare's Festive Tragedy. The ritual foundations of genre (2002), which I have found of considerable interest, especially because it focuses on the motif of the crisis of authority, even though the author does not interpret this crisis systematically in terms of the inversion of the ritual.

My contention then is that the negative characters in Shakespeare's plays, particularly in the tragedies, often can be profitably seen as derived from potentially positive figures through a mechanism similar to the inversion of the ritual. But the inversion in Shakespeare is far from complete: we are confronted with father (or mother) figures that are both demonic and benevolent, and quite often those two aspects may be represented by one and the same character. The same may be said as well of son (or daughter) figures, even though Shakespeare generally seems to side with the younger generation. The mechanism of inversion, it should be remembered, belongs not so much to the ritual itself but rather to those literary genres, such as the myth and the fairy-tale, that are based on it. And it is a regular feature of those genres that they side with the young hero, or heroine, rather than with, as Propp put it "accursed, old cruel rituals" (Propp 74), favouring stern, established patriarchal figures.

2 The question of Shakespeare's religious views is competently dealt with in the chapter "What Form of Prayer Can Serve my Turn" (Bevington, 2008: 106-142). 
The inversion of which rituals are we talking about here? There are, I think, three essential kinds: inversion of the sacrificial ritual, where the passive and obedient victim suddenly rebels; that of the initiatory ritual, where the originally benevolent master of the hero's (or heroine's) initiation is shown to be a monster, or at least potentially a monster; and that of the matrimonial ritual, where the supposedly loving husband (more rarely wife), or lover, is revealed as a highly malicious and unpredictable creature.

The very fact that Shakespeare perverts ancient rituals has long been recognised. Naomi Conn Liebler says: "The absence, misconstruction, or perversion of necessary ritual is a hallmark of Shakesperaean tragedy" (Liebler 25). She goes on to say that:

What these tragedies celebrate, what makes them "festive," is the heroic effort of the protagonist, involving some recognition of ritualistic action at some point in the play, to hold the edges of the world together, to keep Nature's molds from cracking, and all germains from spilling at once, to set right disjointed time. ... In tragedy, of course, the attempt does not work, and the crisis is not averted" (25).

The above quotation is no doubt inspired by Hamlet's famous declaration: "The time is out of joint; O curs'd spite, / That ever I was born to set it right!" (1.5.188). What Liebler apparently fails to notice is that a perversion of the ritual may be itself conducive to regeneration, albeit an imperfect one.

\section{Hamlet's paradoxical initiation}

The most obvious example of the inverted initiation ritual is probably Hamlet, a play in which the hero is confronted with two father figures, his biological father and his stepfather, who is at the same time his uncle. Hamlet ostensibly loves his father and hates his uncle, treating the latter as a grotesque parody of the former, but his relationship with both is in fact much more complicated. Harold Bloom argued that Hamlet's real father was the jester Yorick, while his relationship with the biological father (if the Old Hamlet really was his biological father) was rather cold:

The prince evidently will go to his death having kissed Yorick the king's jester, his substitute father, rather more often than he is likely to have kissed Gertrude or Ophelia, let alone his awesome warrior-father. ... Whose son was Hamlet? ... 'What is really unique about Hamlet is not his unconscious wish to be patricidal and incestuous, but rather his conscious refusal to actually become patricidal and incestuous.' Gertrude dies with Hamlet (and with Claudius and Laertes), but it is remarkable that Hamlet will not kill Claudius until he knows that he himself is dying, and that his mother is already dead. (Bloom, 1998: 418-419) 
Bloom clearly represents Hamlet as an Oedipus manqué, which in this case means a more conscious version of Oedipus, that is, someone who realizes that he is being cornered in an Oedipal situation and knows that he can extricate himself from it, while fulfilling the task of an avenger, only at the cost of his own death. Like a true Oedipal character, he pretends to be going to avenge his father, while in fact he can kill Claudius only as an avenger of his mother and not before the guilt of his uncle for her death is obvious. Moreover, even though the play contains no overt criticism of the principle of revenge, it is remarkable that Hamlet can carry out his act of revenge only in a fit of passion, and never in cold blood.

Bloom seems to be suggesting that Hamlet cleverly contrives to die in order to avoid Oedipus' opprobrium of being accused of parricide and suspected of incest. Without, however, going into the intricacies of a Freudian interpretation of the play, what remains obvious enough is the crisis of Hamlet's "sonship," his inability to call anybody his true father. This might be called the inversion of the initiatory ritual in Hamlet's case. He cannot rely on father figures (and apart from Claudius, Old Hamlet, and Yorick, there is also the Player King, and even Fortinbras who may be considered as potential father figures): he has to be his own master of initiation.

This is clearly a tall order; in an extremely difficult situation he has nobody to rely on. His best friend Horatio is usually absent, his girlfriend Ophelia is a tool in the hands of his enemies, while his mother is presumably the loving wife of his worst enemy. He summarizes this situation in the well-known phrase: "The time is out of joint; O curs'd spite, / That ever I was born to set it right!" (1.5.189-190). ${ }^{3}$

Piotr Mróz, in his Corridors of Power, claims that Hamlet is potentially "an Erasmian ruler", who follows (or rather is prepared to follow, as he never takes the throne) the enlightened rules prescribed for a ruler by Erasmus of Rotterdam (Mróz 1992: 100). As such he is supposed to be the opposite of the Machiavellian ruler, who, like Richard III, is prepared to trample on all moral principles if it suits his interests. This would mean that Hamlet, even though he may count on little help or understanding in his social environment, is strong enough to do without a spiritual father, a master of initiation, because he can draw inspiration, and the necessary moral strength, from his vast erudition, understandable in someone who was a "student of the most renowned medieval European university" (Mróz 101), namely Wittenberg. Actually, the University of Wittenberg was founded in 1502, so it can hardly be called a medieval university. Its reputation was closely connected with the person of Martin Luther, who had been a lecturer there, so it was famous rather as a seedbed for radical, particularly religious, ideas than for purely academic excellence.

${ }^{3}$ Citations from Hamlet come from Lott's edition of the play. 
From Mróz we additionally learn that Hamlet was "a true Erasmian pacifist" and that "Hamlet renounces the raison d'être of war" (Mróz 104), which claim is illustrated by the quotation:

Rightly to be great

Is not to stir without great argument,

But greatly to find quarrel in a straw

When honour's at the stake. (4.4.53-56)

But clearly, this is a misunderstanding. Hamlet's statement is not that of a pacifist, on the contrary. Bernard Lott paraphrases it, and comments on it, in the following way:

It is not a mark of true greatness to take offence without good reason, but (it is a mark of greatness) to dispute over a trivial matter if it is a question of honour. - Hamlet thinks that the reason for Fortinbras's expedition is utterly insignificant, and again realizes to his shame that his own honour is by contrast genuinely at stake. There can be no excuse whatever for his inactivity. (Lott, 1993: 160n.)

Indeed, Hamlet shows himself here to be deeply ashamed of his inactivity. But what does the proper activity consist in? The answer is obvious enough: it consists in killing Claudius, the king of Denmark - hardly a manifestation of pacifism. But even the passage about "being great" is far from being an explicit condemnation of war. It defines moral greatness as readiness to fight, even for an apparently flimsy reason, the moment one feels that one's sense of honour has been wounded.

This definition is naturally a recipe for endless war and rampant militarism. This kind of thinking we would be rather inclined to associate with Hamlet's father, apparently an old fashioned chivalric ruler, who completely embraces the military code that is based on the notion of revenge. His son, however, is famous for his reluctance to accept this code, even though he never openly rejects it.

As Harold Bloom puts it:

Shakespeare, with great care, even guile, gives us a father and a son totally unlike each other, the elder Hamlet and the prince. Of King Hamlet we know that he was a formidable fighter and war leader, much in love (or lust) with his wife. Of the qualities that make the prince so remarkable, the warrior father seems to have possessed none whatsoever. (Bloom, 1998: 390)

If then the young Hamlet uses the kind of language that would have suited his father, we may assume that he is being ironical. So maybe Piotr Mróz is, after 
all, right, and Hamlet may be interpreted as a pacifist. But I would insist he is a pacifist of a peculiar and paradoxical kind. The way he gets rid of Rosencrantz and Guildenstern shows that he did not value highly the life of those whom he perceived as enemies, even though he had used to think of them as friends. Fortinbras, whose name means "strong in arm", is another candidate for a father (rather than a brother) figure in relation to Hamlet. He has the determination and purposefulness that Hamlet lacks so woefully. Hamlet admires him, even though, or perhaps because, Fortinbras is a militarist par excellence. It is hard to say that Fortinbras is a Machiavellian ruler, but we would not be surprised if he were to develop into one. And we seem to like Hamlet better for not being similar to Fortinbras.

Another interesting problem, in this context, is the comparison of Hamlet and Richard III, Erasmian and Machiavellian rulers. They can, no doubt, be contrasted with each other, and yet, in some respects, they are similar enough to each other. Richard, especially when seen as Richard of Gloucester in Henry VI, is in a sense an early version of Claudius:

\section{Richard:}

Why, I can smile, and murder while I smile

And cry „Content” to that which grieves my heart, ...

I can add colours to the chameleon

Change shapes with Proteus for advantages (Henry VI, Part Three 3.2. 182-192) ${ }^{4}$

\section{Hamlet:}

O most pernicious woman!

$O$ villain, villain, smiling, damnèd villain!

My tables - meet it is I set it down

That one may smile, and smile, and be a villain-

At least I am sure it may be so in Denmark. (1.5.105-109)

But the Protean character, which sits so well with the Machiavellian prince, ${ }^{5}$ is also an aspect of Hamlet's own character. One might even suspect that in describing Claudius in this way, he describes himself, even though, instead of smiling, he seems more fond of mocking and scoffing. He describes himself, in front of Ophelia, in the following way:

I am very proud, revengeful, ambitious, with more offences at my beck than I have thoughts to put them in, imagination to give them shape, or time to act

${ }^{4}$ Citations from Henry VI. Parts One, Two, and Three come from Bevington's edition (1988).

5 Lauro Martines calls Machiavelli a Protean figure of Florence (TLS, August 18-25, 2017). 
them in. What should such fellows as I do crawling between earth and heaven? We are arrant knaves, all. Believe none of us. (3.1.125-129)

It is indeed remarkable that here Hamlet reproaches himself for being revengeful, in spite of complaining on so many other occasions of his inability to translate into action his "dull revenge" (4.4.33). The negative aspects of Hamlet have been thoroughly discussed and emphasized, perhaps over-emphasized, by G.Wilson Knight, who said of Hamlet: "He is the ambassador of death walking amid life" (Wilson Knight, 2001: 35), an inhuman monster who is "spreading Hell on earth" (Wilson Knight 42). These are epithets that might well be applied to Richard III and indeed Harold Bloom notices, though with a certain understandable reluctance, an affinity between the two characters: "Nor is our intimacy with Richard more than a foreboding of Hamlet's comprehensive ability to turn the entire audience into so many Horatios" (Bloom 71). It is certainly true that both Hamlet and Richard allow us to get an insight into their minds, and what we find there, in both cases, is extreme bitterness towards themselves and the world, accompanied by the realization that the world may appear different to those with a less pessimistic turn of mind:

\section{Richard:}

But I, that am not shaped for sportive tricks

Nor made to court an amorous looking glass

... I, in this weak piping time of peace

Have no delight to pass away the time

Unless to see my shadow in the sun

And descant on mine own deformity. $(1.1 .14-27)^{6}$

\section{Hamlet:}

What a piece of work is a man! How noble in reason, how infinite in faculty! In form and moving how express and admirable! In action how like an angel, in apprehension how like a god! The beauty of the world. The paragon of animals. And yet, to me, what is this quintessence of dust? Man delights not me. No, nor woman neither, though by your smiling you seem to say so. (2.2.296-303)

What does the peculiar development of Hamlet's personality mean from the point of view of the ritual of initiation? Wilson Knight says:

contrast points the relative significance of the King and his court to Hamlet. They are of the world - with their crimes, their follies, their shallowness, their pomp and glitter, they are of humanity, with all its failings, it is true, but yet of humanity. They assert the importance of human life. They believe in it, in themselves. Whereas Hamlet is inhuman, since he has seen through the tinsel of

${ }^{6}$ Citations from Richard III come from Bevington's edition (1988). 
life and love, he believes in nothing, not even himself, except the memory of a ghost, and his black-robed presence is a reminder to everyone of the fact of death. (Wilson Knight 37)

Mircea Eliade characterizes the result of a successful initiation in the following way:

It is almost possible to say that, in the primitive world, it is the initiation that makes human beings human; before the initiation they do not yet partake in the human condition just because they do not have access to religious life. (Eliade 27)

If Wilson Knight is right, we have to do, in the case of Hamlet, with what might be called the process of anti-initiation. Hamlet has a chance to develop under the tutelage of Claudius, a real king, a person who is a pragmatic politician, but unlike Shakespeare's Macbeth, for example, he shows no propensity to become a ruthless tyrant. He later does turn against Hamlet, but he has no choice; the prince, with his wild behaviour, starts to pose danger to the stability of the state. This is because Hamlet prefers to develop towards death, rather than life, towards inhumanity, rather than humanity, and appropriately enough, since he is under the tutelage of a corpse, or rather a bodiless ghost. On the other hand, it may easily be argued that the "human life" represented by Claudius and his court is based on sham, falsehood and hypocrisy, so what Hamlet really chooses is some deeper, more authentic life, but at a very high price that both he and those dear to him have to pay. It can also be pointed out that basically Hamlet is interested in the death of only one person, his murderous uncle. As he says himself: "Those that are married already, all but one, shall live" (3.1.147-148), so to call him "the ambassador of death" may be an exaggeration.

To be fair to Wilson Knight, I should perhaps emphasize that his theory, if accepted at face value, explains quite neatly why, on the one hand, Hamlet constantly delays his revenge, but on the other never questions either his duty to take revenge or the idea of revenge as such, which he could have easily done by referring to the Christian values of mercy and forgiveness, which is something that Prospero, in a way, does in The Tempest. Wilson Knight's Hamlet seems to put off his revenge for no idealistic reasons, but rather with the truly devilish intention of involving the greatest number of people in it, that is, in order to organize a genuine bloodbath, a festival of death - the killing of just one person is too little for him. Indeed, the scene of the duel, in Act 5 of the play, leads to the almost simultaneous death of four important characters, including Hamlet himself, but it can naturally be argued that Hamlet is responsible there only for one death, that of the king.

René Girard claims that Hamlet was written against the idea of revenge, and the fact that nobody in the play criticizes the model of culture based on 
revenge can be attributed to the rules of the genre: a revenge tragedy, in his opinion, is not a proper place for harangues directed against the notion of revenge (Girard, 1996: 355). But he believes that this void in the conceptual centre of the play, the very absence of arguments against revenge, combined with Hamlet's postponement of his revenge, problematizes and calls into question the ethics based on revenge.

I do not oppose this way of thinking, indeed I regard it as entirely plausible, but I would argue that another way of dealing with the question of revenge in Hamlet is exactly to look at it as an initiation play, where the main task of the hero is not so much to take revenge on his uncle, as to go through a series of difficult tasks contributing to the truly Herculean task of "setting the time right" (1.5.190), and of achieving some kind of self-purification and rebirth. Perhaps Hamlet is indeed a figure remotely similar to Hercules, who performs his twelve labours in the service of the king Eurystheus, who is shown to be a miserable and cowardly character, and who invents difficult tasks for the hero hoping to cause his death. There is strong mutual hatred between Eurystheus and Hercules, who does not kill the king himself, but kills three of his sons, and after Hercules' death, which has no connection with the labours, Eurystheus is killed by Hyllus, a son of Hercules, according to some accounts. An additional analogy consists here in the fact that from Hercules' point of view at least, Eurystheus is a usurper who is sitting on a throne that properly should be held by Hercules. Hercules and Eurystheus are also quite closely related to each other, because Eurystheus is the son of Alcmena's uncle, and Alcmena is Hercules' mother (Grimal, 1997: 95, 384). The story of Hercules and Eurystheus, in the context of Hamlet, has the virtue of containing the motif of revenge, but at the same time decentering it and treating it almost as an afterthought. Hercules also resembles Hamlet in being a fundamentally positive hero, but one who is characterized by fits of foul and nasty temper, which even approaches madness. As it is a pagan myth, we should not naturally expect the legend of Hercules to question the principle of revenge. Hamlet makes in fact an allusion to Hercules and to the first of his labours just before his conversation with the Ghost, which also marks the beginning of Hamlet's "labours":

\section{My fate cries out}

And makes each petty artery of this body

As hardy as the Nemean lion's nerve. (1.5.82-84)

The Nemean lion was killed by Hercules, but with great difficulty, showing the lion to be almost Heracles' equal; and later Hercules graphically identified with that lion by wearing his skin as a suit of armour.

The first allusion to Heracles in Hamlet comes earlier in the second scene of the same act: "My father's brother, but no more like my father / Than 
I to Hercules!" (1.2.152-153). Hamlet emphasizes here that he is not a Hercules, but, on the other hand, he indicates that his father could be likened to Hercules, which makes it more natural for him to think of Herculean strength with reference to himself when he sees the ghost of his father. Finally, there is a reference to Hercules in Act 5: "Let Hercules himself do what he may, / The cat will mew, and dog will have his day." (5.1.271-273).

It seems customary to interpret these enigmatic lines as saying that Hercules here is Laertes, who is putting on heroic airs as an avenger of his father and sister, while the "dog" is Hamlet, who will have his "day", that is, his revenge (in G.R. Hibbard 334n.); but it makes more sense, in my opinion, to think of Hamlet as the Hercules who realizes that his efforts to end the crisis in Denmark (a crisis partly of his own making), even though they may be close to a successful conclusion, are not going to change much in the long run. We may be seeing here, indeed, a covert criticism of the ethics of revenge and its futility.

The most successful of Hamlet's initiatory "labours" (which naturally have the structure of a rite of passage that may easily end in the death of the initiand) is no doubt his avoidance of the trap set for him by Claudius in sending him to England. Claudius's ingenious arrangements to make sure that Hamlet will die as a result of his English mission end in complete failure. Hamlet manages to turn the tables on his enemies, Rosencrantz and Guildenstern, who have pretended to be friends, and returns to England not only unscathed but much more strongly determined to bring his scheme to fruition. This "fruition" does not only involve his killing of Claudius. Hamlet, returning to Denmark at the beginning of Act 5, seems also determined to make peace with Ophelia, Laertes, and the Queen, his mother. In a sense, Hamlet descends into an Otherworld and emerges from it, that is he survives his own death, which is the property only of the greatest cultural heroes, such as Gilgamesh, Odysseus, Aeneas, Theseus, and Hercules.

The singularity and irony of Hamlet's fate consists in the fact that he achieves his goal only to die soon afterwards. This may also be regarded as a peculiar inversion of the ritual, different from the one envisaged by Propp. In Propp, as we remember, we have been invited to consider two inversions: the sacrificial victim is saved, instead of being sacrificed, and the master of the initiation, also called the initiator, is no longer represented as a benevolent figure, "the Wise Old Man" of the myths, but rather as a monster that needs to be killed by the hero. In other words, those who can be expected to die live on, while those who can be expected to assert their domination are put to death. In Hamlet, however, almost everybody dies: the victims, such as Ophelia, the heroes, such as Hamlet and Laertes, the wicked masters, such as Claudius, and also the supposedly virtuous ones, such as the Old Hamlet. It seems deeply ironical that the character who survives and becomes "the winner that takes it 
all" is Fortinbras, who is not even a proper hero, from the point of view of traditional patterns, because he does not seem to go through a near-death experience, that is, through a properly developed rite of passage that could be interpreted as a rebirth. As Joseph Campbell puts it: "Within the soul, within the body social, there must be, if we are to experience long survival-a continuous 'recurrence of birth' (palingenesia) to nullify the unremitting recurrences of death" (Campbell 16).

\title{
Ophelia's victimisation
}

In the case of Ophelia, we seem to encounter a travesty of another ritual, that which involves live sacrifice. The difference between the sacrificial and initiatory rituals need not be great because quite often initiates would fall victim to excessively harsh treatment and die during the ritual (Eliade 86-87). Northrop Frye says the following concerning Ophelia: "Claudius says of the mad Ophelia that without our reason we are mere "pictures", or else beasts, and as Ophelia isn't a beast she must be a picture, a terrible but quite recognizable picture of what she could have been" (Frye 94).

In this way he alludes to the statement made by Claudius on seeing the mad Ophelia:

\author{
Poor Ophelia, \\ Divided from herself and her fair judgement \\ Without the which we are pictures, or mere beasts. (4.5.80-82)
}

It may be claimed, however, that Ophelia becomes both a picture and a beast. In other words, she becomes a sacrificial animal which was often decorated and adorned with ribbons (Hubert \& Mauss 40): "There with fantastic garlands did she come" (4.7.169), before it was ceremoniously killed. Ophelia is not, strictly speaking, killed, but she is often said to have committed suicide, induced to do so by the cruelty and insensitivity of her social environment. On the other hand, the Queen, who was apparently the only eye-witness of Ophelia's death, represents it unequivocally as an unfortunate accident. Bernard Lott remarks: "But one naturally asks why, if the Queen saw all this, she and others did not do something to rescue Ophelia from death by drowning" (Lott 186n.). If Ophelia is considered as a sacrificial victim then the inactivity of the Queen and her entourage can be easily explained. She might be thought of as the high priestess, and, at the same time, Ophelia's demonic, though only potential, mother-in-law, who carries out the act of sacrifice. Eliade, in fact, mentions that a boy, in primitive societies, would be initiated by his potential father-in-law (Eliade 28), and Gertrude certainly is Ophelia's potential mother-in-law. At the same time, 
however, there is no denying that Gertrude looks on Ophelia with great pity and sympathy, as can be seen, for example, when she bids farewell to her at her funeral:

Farewell! I hoped thou shouldst have been my Hamlet's wife;

I thought thy bride-bed to have decked, sweet maid,

And not to have strewed thy grave. (5.1.224-227)

The element of inversion in Ophelia's sacrifice is perceptible in the contrast between her being almost a perfect insider - she tries hard not to distinguish herself in any way, as a dutiful daughter and a loyal lover, and a conventional member of the upper class - and the brutal treatment that she receives and which she is not prepared for. If she were a mythical or fairy tale figure she might have easily reconciled herself to her fate; the inversion consists there in a female victim being saved at the last moment by the unexpected intervention of a male hero, who becomes, naturally, the victim's husband. But Ophelia does not wait for a male saviour; she inverts the ritual herself by going mad and causing trouble to those around her. Sacrificial animals were supposed to accept their death resignedly (Hubert \& Mauss 41). A male saviour does appear, in fact two of them, Ophelia's brother Laertes and her lover Hamlet, but, ironically, not at the last moment, only a while too late, they both jump into her grave protesting their great love for her and solidarity with her, which they apparently had never had time to show when she was alive.

Ophelia illustrates also a cruel inversion of a matrimonial ritual, as far as we think of the ideal marriage conceived as a harmonious union of husband and wife, though in fact the institution of marriage is traditionally associated with the notion of crisis: "Anthropological literature on rituals places marriage in the category of life crises because it marks a transition from one phase of life to another. Indeed, in many cultures it is the most important rite of passage into adulthood." (Kärkkäinen Terian 230). Indeed, the man Ophelia loves turns out to be, in a sense, her worst enemy, first as the murderer of her father, but also as someone who treats her with a curious, and no doubt very painful to her, mixture of malice and indifference. This is at least what we see in the play, though it may be imagined that Hamlet's behaviour towards Ophelia has not always been so off-putting. The conversation between Ophelia and her brother Laertes in Act 1, Scene 3, clearly indicates that Hamlet used to court Ophelia quite assiduously:

Then weigh what loss your honour may sustain,

If with too credent ear you list his songs,

Or lose your heart, or your chaste treasure open

To his unmastered importunity. (1.3.29-32) 
Hamlet's later apparent change of heart and brutality may make us think of a similar motif appearing in the fairy tales about supernatural husbands, the best known literary version of which is probably Apuleius's Cupid and Psyche (see Apuleius 114-157), where the husband turns against his wife the moment he discovers that she has violated, under the influence of her envious sisters, his prohibition and has had a look at him, even though he insisted that he would visit her only at night without being seen. Ophelia may be accused of having committed a similar trespass in allowing Polonius, Claudius and Gertrude to spy on the conversation she has with Hamlet in Act 3, Scene 1. And it is in this scene that Hamlet treats Ophelia particularly harshly in telling her to go to a "nunnery", a female monastery, ${ }^{7}$ which is remarkable in a play that otherwise mentions no religious institutions and refrains from making it clear whether the characters appearing in it are Christians or not. ${ }^{8}$

The obvious difference between the story of Hamlet and Ophelia and that of Cupid and Psyche is that in the former the couple are reconciled and reunited only in a metaphorical and rather heavily ironical sense in the scene of Ophelia's funeral in scene 1 of Act 5. Hamlet's gesture of repudiating Ophelia in the nunnery scene is something more than Cupid's taking offence at his wayward wife; he apparently excludes any possibility of healing his relationship with Ophelia. Another difference is that Ophelia does not break any prohibition imposed on her by Hamlet; as a dutiful daughter she simply gives preference to her filial loyalty to Polonius over her erotic loyalty to Hamlet, without even apparently experiencing this choice as a conflict of loyalties. Presumably, she feels that in obeying her father she acts also in Hamlet's best interest. She could have been right in thinking so if only Hamlet showed himself as being in love with her.

\section{Toxic relationships in Shakespeare's late plays}

Hamlet seems to cast a shadow over the "post-Hamletian" Shakespeare plays. The motif of what might be called "maris fatals" (lethal husbands, by analogy to "femmes fatales"), who break their relations with the women who love them for

7 It is true that the word "nunnery" could in Elizabethan English refer also to a brothel, but it seems that this not the meaning that Hamlet has in mind, as is also confirmed by G.R.Hibbard edition of Hamlet (1998: 243 n.).

8 There is, I realize, another clear, though rather marginal, allusion to Christian, or even Catholic, culture in the words of the Ghost when he speaks about his sudden death for which he could not prepare by taking the sacraments: "Unhouseled, disappointed, unaneled; // No reckoning made ... (1.5.77-78). There is also Act 3, scene 3, where Hamlet decides not to kill the king seeing that he is at prayer, where the Christian context is obvious enough, even though Hamlet's scruples are not motivated by Christian mercy, far from it. 
reasons that are even more flimsy than Hamlet's, is quite persistent in Shakespeare's late plays, not only the so-called Late Romances. I mean the relationship between Othello and Desdemona, Posthumus Leonatus and Imogen (in Cymbeline), and Leontes and Hermione (in The Winter's Tale), but also, in a sense, that between Pericles and Thaisa in Pericles, Prince of Tyre, and Palamon and the Jailer's Daughter from The Two Noble Kinsmen. They are accompanied by a series "pères fatals" (lethal fathers), who might be called unnatural fathers and who partly coincide with the previous list of unnatural husbands and lovers. These can be seen exerting a pernicious influence usually on daughters, occasionally also on sons. Here belong Old Hamlet and Claudius (as Hamlet's murderous stepfather). Then we have King Lear, in relation first of all to Cordelia, Leontes and Perdita (in The Winter's Tale), Pericles and Marina, and finally, Prospero and Miranda. In the case of Macbeth, we are confronted with Lady Macbeth and her husband, who may be said to destroy each other, a "femme fatale" and a "mari fatal".

A special case is that of King Antiochus, from Pericles, who belongs on both lists, because he is both the father and the (incestuous) husband of his unnamed daughter. Their relationship stinks (literally) to high heaven so much that they are both destroyed by a thunderbolt: „A fire from heaven came and shriveled up / Those bodies even to loathing; for they so stunk ..." (2.4.9-10). ${ }^{9}$ Leontes also belongs on both lists because he tries, unsuccessfully, to kill both his wife and his daughter, even though eventually he becomes reconciled with both. Antiochus, unlike Leontes, loves his daughter very much, indeed too much, and, as a result, destroys both his daughter, who is, at the same time, his illicit wife, and himself. However, before he comes to this sorry end, he manages to bring about the death of a great number of his daughter's unfortunate suitors. Naturally also Hamlet cultivates lethal relations as a lover, a son, and a step-son, but he is also a victim of two particularly lethal fathers, his biological father and his stepfather.

\section{Conclusion}

In all the above cases, the figures of fathers and husbands turn out to be inadequate, and they refuse to fulfill their conventional functions. It seems possible to talk about this crisis, the most obvious example of which is found in Hamlet, in terms of the inversion of the initiatory ritual, though not necessarily in the way this inversion is discussed and understood in the works of Vladimir Propp. If the initiation is basically a life enhancing experience, even though it

${ }^{9}$ Citations from Pericles, Cymbeline, The Winter's Tale, The Tempest come from Bevington's edition (1988). 
often contains a brush with death, the inverted initiation, observable in Shakespeare's plays, especially in his tragedies, might sometimes be called a death enhancing experience; but still some initiation, in the positive sense of the word, does take place. The process of the hero's or heroine's maturation involves the killing, or getting rid, of a figure that is the father, or that usurps the father's place.

It is naturally a motif which is, to some extent, derivable from the Senecan model of the revenge tragedy, well known for having influenced the Western Renaissance playwrights. We find there a number of motifs analogous to Shakespeare's tragedies. I ventured to compare Hamlet to Hercules (who is the protagonist of Seneca's Hercules Furens), but Hamlet is usually compared to Orestes (who appears in Seneca's Agamemnon), who avenges the murder of his father Agamemnon for which his mother and her lover Aegisthus are responsible. ${ }^{10}$ Unlike those classical analogies, Hamlet is much more than just a fictional hero from the history of literature. Even G. Wilson-Knight talks of Hamlet as, potentially, "the possessor of spiritual harmony" who could have "restored perfect health to Denmark" (Wilson Knight 48).

As I argue elsewhere (Wicher, 1999: 43-58), Shakespeare's Hamlet may be related to Male Cinderella figures in the tales of magic. As such, he is, like all Cinderellas, who are usually female, a powerful mediator, who can act as an intermediary between this world and the other and between various modes of existence. Hamlet is constantly changing masks, and pretending that he is somebody else, and only at the very end does he reveal his true dignity, or rather this dignity is expressed by his friend Horatio: "Now cracks a noble heart. -Good night, sweet prince; / And flights of angles sing thee to thy rest!" (5.2. 341-42). The same, to a lesser extent, is true of other Shakespearean characters, structurally similar to Hamlet, but all female, such as Cordelia, Perdita, Marina, and Miranda, who also achieve an inversion of the ritual; they seem doomed and lost, but later they come into their own, though in the case of Cordelia this means only a moment of triumph, followed by death. They are beset with problem fathers, such as Lear, Leontes, Pericles and Prospero, who are not necessarily evil because, after all, Shakespeare's plays are not fairy tales or

${ }^{10}$ Aegisthus is Agamemnon's first cousin, a son of his uncle Thyestes, so almost as in the case of Claudius and Old Hamlet, the murderer is the murdered king's close relation. But one might connect Hamlet also with Aegisthus himself, who kills his uncle Atreus, apart from also killing his uncle's son Agamemnon, in order to avenge his father Thyestes, who, admittedly, was not killed by Atreus, but Atreus killed Thyestes' three sons and served them to his brother as a meal. Therefore Aegisthus is also avenging his brothers, or rather half-brothers, because his mother is Thyestes' own daughter, so he is a fruit of an incestuous relationship, and his mother is also his half-sister. 
myths, so his characters display often a complexity beyond the reach of simpler narrative forms.

Edward Berry observes that "In Shakespearean comedy the crucial obstacles are usually psychological, not social or metaphysical" (Berry 9). The problem is that sometimes it is difficult, especially In Shakespearean tragedies, to separate psychological obstacles from social ones. Hamlet and Cordelia's refusal to accept the roles imposed on them may be attributed to their stubborn and egotistic characters, but their rebellion reveals also a longing for a better social order, less dominated by hypocrisy and the desire to keep up appearances. As has been observed by Liebler:

Tragedy manifests the decentering of authority, it is the image of authority in crisis. The problem of sovereign (central, supreme, ordering) authority is enacted in the crisis faced by the tragic protagonist whose behavior reflects a disruption or discontinuity, both producing and produced by that behavior. (Liebler 8)

Such protagonists can be said to have inverted a ritual that deserved to be inverted, and the very gesture of inversion had a liberating quality, even though it had dire consequences for the personal lives of the protagonists and those around them.

\section{WORKS CITED}

Apuleius, Lucius. The Golden Ass, trans. Robert Graves. Harmondsworth, Middlesex: Penguin Books, 1950.

Berry, Edward. Shakespeare's Comic Rites. Cambridge et al.: Cambridge University Press, 2010.

Bevington, David. Shakespeare's Ideas. More Things in Heaven and Earth, Malden, Oxford, Chichester: Wiley-Blackwell, 2008.

Bloom, Harold. Shakespeare: The Invention of the Human. New York: Riverhead Books, 1998.

Campbell, Joseph. The Hero with a Thousand Faces. London: Fontana Press, 1993.

Eliade, Mircea. Initiation, rites, sociétés secrètes. Naissances mystiques (Initiation, Rites, Secret Societies. Mystical Births). La Flèche (Sarthe): Gallimard, 1992.

Frye, Northrop. Northrop Frye on Shakespeare. Ed. Robert Sandler. New Haven and London: Yale University Press, 1986.

Girard, René. Szekspir. Teatr zazdrości (A Theater of Envy: William Shakespeare). Warszawa: Wydawnictwo KR, 1996.

Grimal, Pierre. Stownik mitologii greckiej i rzymskiej (A Dictionary of Greek and Roman Mythology). Wrocław, Warszawa, Kraków, Gdańsk, Łódź: Ossolineum, 1987. 
Hubert, Henri and Marcel Mauss. Esej o naturze i funkcji ofiary (Sacrifice: Its Nature and Function), trans. Lech Trzcionkowski. Kraków: Zakład Wydawniczy NOMOS, 2003.

Liebler, Naomi Conn. Shakespeare's Festive Tragedy. The ritual foundations of genre. London and New York: Routledge, 2002.

Mróz, Piotr. Corridors of Power. An Aesthetic Study of the Machiavellian and Erasmian Rulers in Shakespeare. Kraków: Uniwersytet Jagielloński, 1992.

Propp, Władimir. Historyczne korzenie bajki magicznej (Historical Roots of the Wondertale), trans. J. Chmielewski. Warszawa: Wydawnictwo KR, 2003.

Propp, Vladimir. Theory and History of Folklore. Ed. Anatoly Liberman, trans. A.Y. Martin \& R.P. Martin. Manchester: Manchester University Press, 1984.

Shakespeare, William. Hamlet. Ed. G.R. Hibbard. The Oxford Shakespeare. Oxford, New York et al.: Oxford University Press, 1998.

Shakespeare, William. Hamlet. Ed. Bernard Lott. New Swan Shakespeare. Burnt Mill, Harlow: Longman, 1993.

Shakespeare, William. Henry VI. Parts One, Two, and Three. Ed. David Bevington. Toronto et al.: Bantam Books, 1988.

Shakespeare, William. Pericles, Cymbeline, The Winter's Tale, The Tempest. Ed. David Bevington. Bantam Books, Toronto et al., 1988.

Shakespeare, William. Richard III. Ed. David Bevington. New York et al.: Bantam Books, 1988.

Thompson, Stith. The Folktale. Berkeley, Los Angeles, London: University of California Press, 1977.

Wicher, Andrzej. "Hamlet as an 'Ash-Boy', i.e. a Male Cinderella." In Anglica - approaches to literature, culture, and language. Eds. Andrzej Weseliński, Jerzy Wełna. Warszawa: Wydawnictwa Uniwersytetu Warszawskiego, 1999.

Wilson Knight, George. The Wheel of Fire. London and New York: Routledge Classics, 2001.

\section{Internet sources}

Faherty, Robert L. "Sacrifice". Encyclopedia Britannica [online], Invalid Date, https://www.britannica.com/topic/sacrifice-religion [Accessed on 15 October 2020].

Kärkkäinen Terian, Sara. Marriage Rituals [online]. Available from: http://cw.routledge. com/ref/religionandsociety/rites/marriage.pdf [Accessed on 15 October 2020].

Martines, Lauro, Political animal. Lauro Martines on Niccolò Machiavelli: the protean figure of Florence [online]. Times Literary Supplement (August 18-25, 2017, No. 5968/5969). Available from: https://www.the-tls.co.uk/articles/politicalanimal/ [Accessed on 15 October 2020].

N.B. Inquiries Journal 2010, vol. 2, no. 1, p. 1/1. The Relationship between Fathers and Sons in Shakespeare [online]. Available from: http://www.inquiriesjournal .com/articles/148/the-relationship-between-fathers-and-sons-in-shakespeare [Accessed on 15 October 2020]. 